\title{
Psychological capital, work engagement and organisational commitment amongst call centre employees in South Africa
}

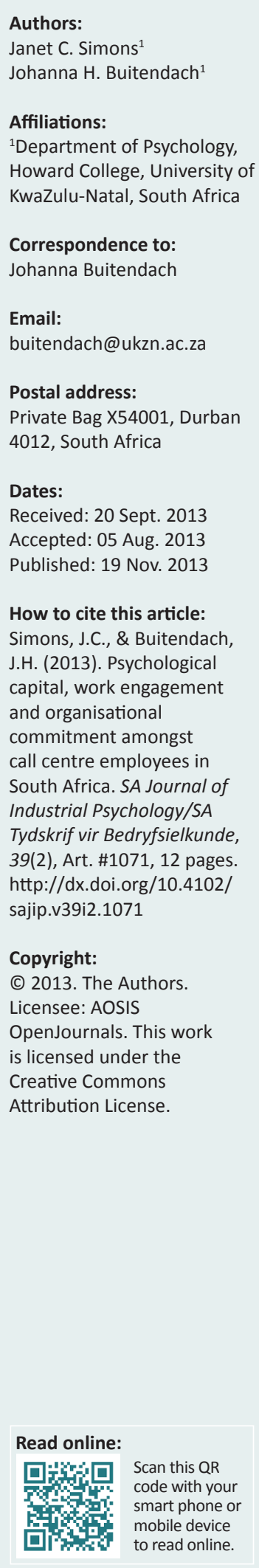

Authors:

Janet C. Simons

Affiliations:

${ }^{1}$ Department of Psychology, Howard College, University of KwaZulu-Natal, South Africa

\section{Correspondence to:}

Email:

\section{Postal address:}

Private Bag X54001, Durban

\section{Dates}

Received: 20 Sept. 2013

Accepted: 05 Aug. 2013

How to cite this article: Simons, J.C., \& Buitendach, and organisational commitment amongst Industrial Psychology/SA Tydskrif vir Bedryfsielkunde, 39(2), Art. \#1071, 12 pages. http://dx.doi.org/10.4102/

Copyright:

(C) 2013. The Authors Licensee: AOSIS is licensed under the Creative Commons Attribution License.
Orientation: The development of psychological capital amongst call centre employees could have an impact on positive work-related attitudes and behaviour; such as work engagement and organisational commitment.

Research purpose: The purpose of the research was to determine the relationship between psychological capital, work engagement and organisational commitment amongst call centre employees; and further, to determine whether psychological capital and work engagement hold predictive value for the organisational commitment of call centre employees.

Motivation for the study: There is a gap in research in understanding and enabling positive resource capacities in highly stressful work contexts such as call centres.

Research design, approach and method: A cross-sectional survey design was used. A sample of 106 call centre employees from a South African organisation participated in the research. The measuring instruments included a demographic questionnaire, the Psychological Capital Questionnaire (PCQ), the Utrecht Work Engagement Scale (UWES) and the Organisational Commitment Questionnaire (OCQ).

Main findings: Significant positive relationships were found between psychological capital, work engagement and organisational commitment. The results showed work engagement as being the only significant predictor of organisational commitment.

Practical/managerial implications: Call centre employers need to develop and implement workplace interventions that would increase the psychological capital of call centre employees.

Contribution/value-add: The research findings will benefit both call centre employees and management. The study highlighted the importance of the role of optimism as a subdimension of psychological capital in developing work engagement and organisational commitment amongst call centre employees.

\section{Introduction}

The call centre environment is one of the fastest-growing segments in the service sector, both in South Africa and internationally (Swart, 2006). Employees in the South African call centre sector have increased from 50000 in 2005 to 180000 in 2010 and it is predicted that approximately 100000 new jobs will be created in the country by 2015 (Thomas, 2010). Holman (2003) has conducted much research on the demanding and stressful nature of call centre work. Call centre work is characterised by a sensory overload, rapid technological, product and service changes, work pressure and high workloads (Swart, 2006). The consequences of this may include stress, burnout, anxiety, absenteeism and performance problems (Lombard, 2009). In response to the above, call centre employees need to develop positive psychological resources as they have an impact on positive work-related attitudes and behaviours (Avey, Wernsing \& Luthans, 2008). A review of the literature indicates that little has been done with regard to exploring the role of state-like characteristics and other personal resources in managing organisational demands or facilitating employee performance in call centres (Lombard, 2009; Zapf, Isic, Bechtoldt \& Blau, 2003). In this regard, positive psychological resource capacities, such as psychological capital, have been shown to have an impact on desired work-related outcomes such as improved attitudes to work engagement and behaviours of organisational commitment in various work contexts (Youssef \& Luthans, 2007). In our review of the literature, the authors have not found any study investigating psychological capital and its relationship with work engagement and organisational commitment in a call centre. Therefore, the current study investigates the relationship between Psychological capital (PsyCap), work engagement and organisational commitment and determines whether PsyCap and work engagement predict organisational commitment. 
Psychological capital is a core concept in positive organisational behaviour (POB) literature. Positive organisational behaviour is defined as: 'the study and application of positively-oriented human resource strengths and psychological resource capacities that can be measured, developed, and effectively managed for performance improvement in today's workplace'. (Luthans, 2002a, p. 59). Positive organisational behaviour and PsyCap are rooted in the Positive Psychology movement (Donaldson \& Ko, 2010). The Positive Psychology movement places emphasis on the concepts of strengths, virtues, excellence, thriving, happiness, flourishing, resilience, flow and optimal functioning (Donaldson \& Ko, 2010).

One example of POB-based approaches to organisational research is the Broaden-and-Build Theory of positive emotions. This study adopts Fredrickson's (2004) broadenand-build theory as the theoretical framework that provides the lens for understanding the antecedents that are linked to the work-related outcomes of work engagement and organisational commitment. The theory maintains that positive emotions such as joy, contentment and interest can broaden an individual's thought-action repertories by expanding the thoughts and actions that come to an individual's mind. Therefore, positive emotions broaden an individual's thinking, thus enabling a more broadened outlook, which in turn can help with the development of personal resources. The resources can be social, psychological, physical and cognitive. The capacity of an individual to both broaden and experience positive emotions is important to one's ability to grow and flourish (Fredrickson, 2004).

\section{Psychological capital}

Psychological capital is a core construct of POB (Luthans \& Youssef, 2004). It is proposed as an important composite construct that can assist in addressing human capital issues in organisations. PsyCap consists of four psychological resource capacities, namely, hope, optimism, resilience and self-efficacy (Luthans, Luthans \& Luthans, 2004). Psychological capital places emphasis on the positive nature and strengths of employees and the role this has on fuelling employees' growth and performance (Luthans, Avolio, Walumbwa \& Li, 2005). The psychological dimensions of PsyCap have been linked to overall workplace attitudes and performance (Luthans, Youssef \& Avolio, 2007) such as higher job satisfaction, work happiness and citizenship (Avey et al., 2008; Youssef \& Luthans, 2007). Youssef and Luthans (2007) maintain that the relationship between PsyCap and work engagement and organisational commitment have been supported empirically in various organisational contexts.

The PsyCap constructs of hope, optimism, resilience and self-efficacy will be presented in brief below.

\section{Hope}

Snyder (2002) explains hope as a multidimensional construct that consists of an individual's 'willpower' and 'waypower'. Willpower is an individual's agency or determination to achieve goals and 'waypower' is one's ability to devise alternative pathways and contingency plans in order to achieve a goal in the face of obstacles (Snyder, Irving \& Anderson, 1991). Hope enables individuals to be motivated to attain success with the task at hand by looking for the best pathway (Avey et al., 2008). The components of hope thus complement each other (Weick \& Quinn, 1999).

Hope has made a significant contribution to positive PsyCap and has demonstrated importance in the workplace (Duggleby, Cooper \& Penz, 2009; Luthans \& Jensen, 2002). For instance, researchers discovered that hope predicted job performance beyond cognitive ability and self-efficacy (Peterson, Walumbwa, Byron \& Myrowitz, 2009). Moreover, Youssef and Luthans (2007) found that it had a positive effect on employee satisfaction, organisational commitment and work happiness. Hope also protects an individual's perceptions of vulnerability, uncontrollability and unpredictability (Snyder, 2002). Weick and Quinn (1999) thus believe that sustaining employees' hope is necessary for employee wellbeing.

\section{Optimism}

Optimism is more closely associated with positive psychology than the other constructs (Luthans et al., 2004). It is regarded as being a realistic, flexible and dynamic construct that can be learned and developed (Peterson, 2000). Optimism is defined by persistence and pervasiveness - two key dimensions of how people explain events (Carver \& Scheier, 2002). People with an optimistic outlook see setbacks as challenges and opportunities that can eventually lead to success (Luthans et al., 2005). These individuals persevere in the face of obstacles (Stajkovic \& Luthans, 1998). In the work context, an optimistic employee is better able to assess external, temporary and situational circumstances (Youssef \& Luthans, 2007).

In a South African study, Rothmann and Essenko (2007) found that dispositional optimism had a direct effect on exhaustion and cynicism amongst support staff in a higher education institution. Other research has shown that optimism correlated with employee engagement and employee performance (Arakawa \& Greenberg, 2007; Medlin \& Faulk, 2011). It is the authors' view that optimism forms a vital part of a call centre employee's resource capacities as their optimistic approach to stressful and challenging situations could potentially have a positive impact on the achievement of work-related goals.

\section{Resilience}

Rutter (1987) defined resilience as people's ability to manipulate their environment successfully in order to protect them from the negative consequences of adverse events. Luthans (2002b) extended this definition to include people's ability to 'bounce back' from adversity. In this regard, resilient people move on in life after having had a stressful experience or event such as personal adversity, conflict and/ or failure. Therefore, resilience highlights the strength of the individual and his or her coping resources to successfully resolve and/or manage testing situations (Baumgardner \& Crothers, 2010). 
Research has attempted to link resilience positively with workplace performance (Luthans et al., 2007). Research indicates that when employees experience negative events in the workplace, individuals with high PsyCap are more likely to adapt positively and bounce back from those events, thus preventing the escalation and development of intentions to quit (Luthans, Avey, Avolio, Norman \& Combs, 2006). Philippe, Lecours and Beaulieu-Pelletier (2008) found that resilience has been associated with positive emotions, especially when an individual is experiencing a taxing event. Research has further indicated possible links between resilience, commitment and work engagement, as well as a positive link between resilience and work happiness (Luthans, Avolio, Avey \& Norman, 2007; Youssef \& Luthans, 2007). Resilience has also been linked to more effective coping mechanisms and behaviours that facilitate growth and development. In this regard, Youssef and Luthans (2008) propose that this may lead to higher overall commitment to the organisation, even though employees may experience their current situation and job requirements as unfavourable.

\section{Self-efficacy}

Stajkovic and Luthans (1998) define self-efficacy as an individual's conviction regarding their ability to mobilise the motivation, cognitive resources and courses of action necessary to accomplish a specific task within a given context. An individual's perception and interpretation of events will influence and determine how they will address difficult challenges, as well as how they will experience of stress symptoms (Bandura, 2000). Those with high levels of efficacy will perceive challenges as surmountable, given sufficient competencies and effort (Avey, Luthans \& Jensen, 2009).

Self-efficacy is a high-order construct of PsyCap (Luthans et al., 2007). This positive psychological resource capacity of confidence, which is a state, can be developed. It is described as an enthusiastic and independent concept, being linked closely with work-related performance (Luthans et al., 2004).

Self-efficacy has also been shown to be related to the socialisation and retention of new employees (Bauer, Bodner, Erdogan, Truxillo \& Tucker, 2007); as well as being related to organisational commitment and turnover intentions of existing staff (Harris \& Cameron, 2005). In a South African study, Rothmann (2003) found that positive psychological constructs such as self-efficacy could have a mediating effect on occupational stress, burnout and work engagement. There are no studies in South African call centres on self-efficacy and its relation to work-related outcomes.

\section{Work engagement}

Bakker, Demerouti and Schaufeli (2003) define work engagement as a positive, fulfilling, work-related state of mind that is characterised by vigour, dedication and absorption. Vigour is characterised by high levels of energy and mental resilience whilst working; dedication refers to being strongly involved in one's work and experiencing a sense of importance, enthusiasm, inspiration, pride and challenge; and absorption is characterised by being fully concentrated on and happily engrossed in one's work, whereby time passes quickly and one experiences difficulties with regard to detaching oneself from work (Schaufeli, Salanova, GonzálezRomá \& Bakker, 2002).

Kahn (1990) outlined how engaged employees express physical, cognitive and emotional components when applying themselves in their work role. Employees need to have physical, emotional and psychological resources so as to complete their work and to identify with it. Maslach and Leiter (1997) conceptualised engagement and burnout as being opposite poles of a continuum of work-related wellbeing. However, Schaufeli and Bakker (2004) believe that these two concepts cannot have a perfect negative correlation.

Work engagement research has confirmed the relationship between engagement and positive organisational outcomes (Donaldson \& Ko, 2010). These include performance (Kahn, 1990), organisational commitment (Demerouti, Bakker, de Jonge, Janssen \& Schaufeli, 2001), low turnover intention (Halbesleben \& Wheeler, 2008), job satisfaction (May, Gilson \& Harter 2004; Schaufeli \& Bakker, 2004) and good health and positive work affect (Rothbard, 2001). Disengagement is central to the problem of an individual's lack of commitment and motivation (May et al., 2004).

\section{Organisational commitment}

Organisational commitment refers to the nature of the employee's attachment to their organisation (Shahnawaz \& Jafri, 2009) and to the employee's identification with and involvement in a particular organisation (Mowday, Porter \& Steers, 1982).

Allen and Meyer (1990) proposed a three-component model of organisational commitment: affective, continuance and normative commitment. Affective commitment refers to the employee's emotional attachment to, identification with and involvement in the organisation. Continuance commitment refers to commitment based on the benefits of staying with the organisation versus the costs that are associated with leaving the organisation. Normative commitment refers to an employee's feeling of obligation to remain with the organisation. Much research has focused on the affective component of organisational commitment (Field \& Buitendach, 2011). The affective component has the strongest and most consistent relationship with desirable workplace outcomes (Arzu Wasti, 2003).

\section{Relationship between constructs}

Research has shown that psychological resource capacities do have a positive impact on work-related outcomes such as work engagement and organisational commitment (Youssef $\&$ Luthans, 2007). The different dimensions of PsyCap have been shown to have a positive correlation with organisational commitment (Luthans, Norman, Avolio \& Avey, 2008). Empirical research has found that organisational commitment 
is correlated with hope, optimism, resilience and self-efficacy (Sinha, Talwar \& Rajpal, 2002; Youssef \& Luthans, 2007). Buys and Rothmann (2010) reported a positive correlation between organisational commitment and work engagement, concluding that engaged employees had better social functioning and affective commitment. Researchers have also presented evidence that work engagement and organisational commitment have a complementary relationship (Demerouti et al., 2001; Macey \& Schneider, 2008).

However, Janse van Rensburg (2010) asserts that there is a lack of published studies on the strengths and psychological capacities of call centre employees. More specifically, to the knowledge of the researchers within the South African context, no research has addressed the relationship between the PsyCap, work engagement and organisational commitment of call centre employees.

The purpose of the present study was to address this gap in the research by identifying the relationships that may exist between PsyCap, work engagement and organisational commitment amongst South African call centre employees. It also aimed to establish whether PsyCap and work engagement have an impact on the organisational commitment of call centre employees. The development of the state-like construct of PsyCap can be facilitated through human resources interventions such as training and development (Luthans et al., 2006). These interventions could potentially facilitate the skills and coping strategies required in the call centre environment. Furthermore, the selection of call centre employees could also potentially include PsyCap profiles in order to ensure sustainability in the call centre environment.

\section{Research design \\ Research approach}

The research design used in the present study was a crosssectional design, whereby a sample was drawn from a specified population (Huysamen, 1994; Shaughnessy \& Zechmeister, 2000). According to Shaughnessy and Zechmeister (2000) this type of research design is ideally suited to descriptive and predictive functions and is thus well suited to achieve the aims and objectives of the present study.

\section{Research method}

\section{Research participants}

A nonprobability convenience sample was used in the study. Shaughnessy and Zechmeister (2000) explain that convenience sampling involves selecting respondents primarily on the basis of their availability and willingness to respond. This was the preferred sampling technique as it had the practical benefits of being less time-consuming and more efficient (Goodwin, 2004). Employees who made themselves available in their own time were selected to participate in the study (Babbie \& Mouton, 2001). The research participants were call centre employees from one call centre situated in KwaZulu-Natal, South Africa.
Characteristics of participants: Table 1 contains the participants' biographical data. The sample comprised more women $(70.8 \%)$ than men $(29.2 \%)$, which is understandable as there are generally more women than men working in call centres. Many $(n=50)$ of the participants were 25-35 years old. There were differences in terms of marital status and academic qualifications. Most participants had been working in the call centre for less than five years.

Of the participants, $19.8 \%$ had previous call centre experience, $11.3 \%$ had previous work experience in the customer service industry and $7.5 \%$ had previous experience in the administrative, health insurance or finance sectors.

\section{Measuring instruments}

The data collection consisted of a biographical data sheet and three scales. The biographical information included the participants' gender, age group, marital status, years working within the organisation (tenure), highest qualification attained and work experience.

The Psychological Capital Questionnaire (PCQ) (Luthans et al., 2007) measures PsyCap and comprises four subscales, namely, hope, optimism, resilience and self-efficacy. The PCQ is a self-report questionnaire and has 24 items. Each subscale consists of six items. All the responses for the PCQ are anchored on a six-point Likert scale with the response options: 1 = strongly disagree, 2 = disagree, 3 = somewhat disagree, 4 = somewhat agree, $5=$ agree, $6=$ strongly agree. Psychological capital includes statements such as: 'At the present time, I am energetically pursuing my goals' (hope); 'I am optimistic about what will happen to me in the future as it pertains to work' (optimism); 'I usually manage difficulties one way or another at work' (resilience); and 'I feel confident helping to set targets/goals in my work area' (self-efficacy).

\begin{tabular}{|c|c|c|c|}
\hline Variables & Item & $f$ & $\%$ \\
\hline \multirow[t]{2}{*}{ Gender } & Male & 31 & 29.2 \\
\hline & Female & 75 & 70.8 \\
\hline \multirow[t]{5}{*}{ Age } & 24 years and younger & 40 & 37.7 \\
\hline & $25-35$ years & 50 & 47.2 \\
\hline & $36-45$ years & 16 & 15.1 \\
\hline & $46-55$ years & 0 & 0 \\
\hline & 56 years and older & 0 & 0 \\
\hline \multirow[t]{5}{*}{ Marital status } & Single & 57 & 53.8 \\
\hline & Widowed & 0 & 0 \\
\hline & Living with partner & 3 & 2 \\
\hline & Divorced & 1 & 0.9 \\
\hline & Married & 45 & 42.5 \\
\hline \multirow[t]{3}{*}{ Highest qualification } & Matric certificate & 63 & 59.4 \\
\hline & Diploma & 30 & 28.3 \\
\hline & University degree & 13 & 12.3 \\
\hline \multirow[t]{3}{*}{ Tenure } & Less than 5 years & 88 & 83 \\
\hline & $6-10$ years & 18 & 17 \\
\hline & $11-20$ years & 0 & 0 \\
\hline \multirow[t]{4}{*}{ Work experience } & Call centre industry & 21 & 19.8 \\
\hline & Customer service industry & 12 & 11.3 \\
\hline & Administrative/health insurance/finance & 8 & 7.5 \\
\hline & Artisan/technical & 3 & 2.8 \\
\hline
\end{tabular}

$f$, frequency. 
The resulting score represents an individual's level of PsyCap. Each of the four subscales of PsyCap was drawn from established scales that had been published previously and had been tested and used in recent workplace studies (Avey, Luthans \& Youssef, 2010a). The Cronbach alphas reported in their study were as follows: hope 0.87 ; optimism 0.78 ; resilience 0.72 ; and self-efficacy 0.87. Acceptable reliability coefficients have been reported in South African samples for the four dimensions with the alpha coefficients ranging from 0.67 to 0.83 (Herbert, 2011).

The Utrecht Work Engagement Scale (UWES) (Schaufeli et al., 2002) was used to measure work engagement. The UWES is a self-report questionnaire and has 17 items. The UWES comprises three subscales, namely, vigour (6 items), dedication (5 items) and absorption (6 items). The UWES includes statements such as: 'I am bursting with energy in my work' (vigour); 'I find my work full of meaning and purpose' (dedication); and 'I am immersed in my work' (absorption). The UWES is scored on a seven-point Likert scale, varying from $0=$ never to $6=$ every day. The UWES has been found to have acceptable reliability coefficients that have been reported both internationally and in South Africa. Storm and Rothmann (2003) obtained alpha coefficients for internal consistency and reliability for the three subscales of between 0.78 and 0.89 in a South African context.

The Organisational Commitment Questionnaire (OCQ) (Allen \& Meyer, 1990) has three subscales that measure different types of organisational commitment, namely, affective commitment, cognitive commitment and normative commitment. The OCQ consists of 18 items and is scored on a five-point Likert type scale ranging from 1 = strongly disagree to 5 = strongly agree. Acceptable reliability coefficients of above 0.80 have been reported for every one of these subscales (Suliman \& Iles, 2000). In a South African study, Jackson, Rothmann and van de Vijver (2006) reported an alpha coefficient of 0.88 . Heymans (2002) obtained a Cronbach coefficient of 0.80 for the affective scale, 0.69 for the continuance scale and 0.74 for the normative scale. The OCQ statements include: 'I feel as if this organisation's problems are my own' (affective commitment); 'It would be very hard for me to leave the organisation right now, even if I wanted to' (continuance commitment); and 'I would feel guilty if I leave my organisation right now' (normative commitment).

\section{Statistical analysis}

The Statistical Package for the Social Sciences program (version 21.0) was used to carry out the statistical analysis (IBM SPSS Inc., 2012). Descriptive statistics (means, medians, standard deviations, skewness and kurtosis) were used to describe the data. Confirmatory factor analysis was undertaken in order to determine the factor structure of the PCQ, UWES and the OCQ. Cronbach alpha coefficients $(\alpha)$ were used to assess the internal consistency or reliability of the measuring instruments. A cut-off point of $p<0.05$ was set for the statistical significance of the results. Effect sizes (Cohen, 1988) were used to decide on the practical significance of the findings. Pearson product-moment correlation coefficients were used to specify the relationship between PsyCap, work engagement and organisational commitment. The statistical significance levels used in this study were $p \leq 0.05$ and $p \leq 0.01$ respectively. Pearson product-moment correlation coefficients were then also used to specify the relationships between the variables. A cut-off point of 0.30 (medium effect; Cohen, 1988) was set for the practical significance of correlation coefficients.

Cohen's (1988) benchmark values are used as a qualitative judgement to determine whether the practical significance is 'small', 'medium' or 'large'. The guidelines given by Cohen (1988) were 0.1: small effect; 0.3: medium effect; and 0.5: large effect. Practical significance for the study was set at 0.30. A medium effect size ranges from 0.30 to 0.49 and a large effect size ranges from 0.50 and above (Steyn, 2011).

Hierarchical regression analysis (Field, 2005) was conducted to determine whether psychological capital and work engagement held predictive value for the organisational commitment.

\section{Results

Descriptive statistics and Cronbach alpha
coefficients

Table 2 provides an overview of the descriptive statistics minimum, maximum, mean, standard deviation, skewness and kurtosis, as well as the Cronbach alpha coefficients of the PCQ, the UWES and the OCQ. The statistical ranges of -2 to 2 for skewness and -7 to 7 for kurtosis are acceptable; therefore this data set has acceptable normality and lends itself to further analysis. All three questionnaires (PCQ, UWES and OCQ) had acceptable reliability with Cronbach's alpha coefficients being greater than 0.9 for the first two and greater than 0.7 for the OCQ. The reliability coefficient for PCQ was 0.91 and for the constructs of hope, optimism, resilience and self-efficacy, $0.76,0.72,0.90$ and 0.87 , respectively. The UWES reliability coefficient was 0.95 and the constructs of vigour, dedication and absorption had internal reliabilities of 0.90 , 0.86 and 0.85 , respectively. The internal reliability of the OCQ was 0.79 and the internal reliabilities of the constructs of affective, continuance and normative commitment were 0.74 , 0.65 and 0.74 , respectively.

Confirmatory factor analyses of the three questionnaires indicated that four factors could be extracted for the PCQ, explaining $62.16 \%$ of the total variance; three factors could be extracted for the UWES, explaining $56 \%$ of the total variance; and three factors could be extracted for the OCQ, explaining $53.23 \%$ of the total variance.

\section{Pearson product-moment correlation coefficients}

Pearson product-moment correlation coefficients were used in order to examine the strength of the relationships between the variables of the present study. Table 3 reports the correlations between the constructs of psychological capital (PsyCap measure), work engagement (UWES measure) and organisational commitment (OCQ measure). 
The relationship between the Psychological Capital Questionnaire, the Utrecht Work Engagement Scale and the Organisational Commitment Questionnaire (total scores)

Table 3 shows that a positive statistically- and practicallysignificant relationship was found between PsyCap (hope, optimism, resilience and self-efficacy) and work engagement (vigour, dedication and absorption), ( $p \leq 0.01 ; r=0.73$ ). Also, a positive statistically- and practically-significant relationship was found between PsyCap and organisational commitment (affective, continuance and normative commitment), ( $p \leq$ $0.01 ; r=0.35)$. Furthermore, a statistically- and practicallysignificant relationship was found between work engagement (total score) and organisational commitment (total score) $(p \leq 0.01 ; r=0.63)$.

\section{The relationship between the Psychological Capital Questionnaire and the Utrecht Work Engagement Scale subscales}

Positive statistically- and practically-significant relationships were found between PsyCap (total score) and vigour, dedication and absorption ( $p \leq 0.01 ; r=0.85,0.65$ and 0.65 , respectively). Also, positive statistically- and practically-significant relationships were found between work engagement (total) and resilience $(p \leq 0.01 ; r=0.82)$, optimism $(p \leq 0.01 ; r=0.68)$, self-efficacy $(p \leq 0.01 ; r=0.42)$ and hope $(p \leq 0.01 ; r=0.44)$. On further inspection of the subscales of PsyCap and work engagement, positive statistically- and practically-significant relationships were found between vigour and self-efficacy $(p \leq 0.01 ; r=0.45)$, resilience $(p \leq 0.01 ; r=0.48)$ and hope $(p \leq 0.01 ; r=0.49)$, as well as between vigour and optimism $(p \leq 0.01 ; r=0.69)$. Positive statistically- and practicallysignificant relationships were found between dedication and self-efficacy ( $p \leq 0.01 ; r=0.35)$, resilience $(p \leq 0.01 ; r=0.33)$ and hope $(p \leq 0.01 ; r=0.32)$, as well as between dedication and optimism $(p \leq 0.01 ; r=0.61)$ ) Positive statistically- and practically-significant relationships were also found between absorption and self-efficacy ( $p \leq 0.01 ; r=0.39)$, resilience $(p \leq 0.01 ; r=0.34)$ and hope $(p \leq 0.01 ; r=0.42)$, as well as between absorption and optimism $(p \leq 0.01 ; r=0.64)$.

\section{The relationship between the Psychological Capital Questionnaire and Organisational Commitment Questionnaire subscales}

Table 3 shows that positive statistically-significant relationships were found between organisational commitment (total) and self-efficacy and hope $(p \leq 0.05 ; r=0.20$ and 0.26 , respectively). Also shown in Table 3 are the positive statistically- and practically-significant relationships found

TABLE 2: Descriptive statistics.

\begin{tabular}{|c|c|c|c|c|c|c|c|}
\hline Variable & Minimum & Maximum & $M$ & SD & Skewness & Kurtosis & $\alpha$ \\
\hline PsyCap total & 70.00 & 141.00 & 113.34 & 16.77 & -0.270 & -0.822 & 0.91 \\
\hline Self-efficacy & 6.00 & 36.00 & 29.60 & 5.44 & -1.25 & 2.517 & 0.87 \\
\hline Resilience & 6.00 & 36.00 & 27.61 & 6.16 & -0.83 & 0.732 & 0.90 \\
\hline Hope & 8.00 & 36.00 & 28.94 & 4.75 & -0.99 & 2.71 & 0.76 \\
\hline Optimism & 10.00 & 36.00 & 26.13 & 4.99 & -0.041 & 0.31 & 0.72 \\
\hline UWES total & 6.00 & 102.00 & 77.17 & 22.24 & -1.67 & 2.900 & 0.95 \\
\hline Dedication & 1.00 & 30.00 & 22.98 & 6.57 & -1.38 & 2.732 & 0.86 \\
\hline Absorption & 0.00 & 30.00 & 22.76 & 6.83 & -1.663 & 3.006 & 0.85 \\
\hline Organisational commitment total & 28.00 & 84.00 & 58.76 & 10.99 & -0.573 & 0.29 & 0.79 \\
\hline Affective commitment & 6.00 & 30.00 & 20.40 & 5.20 & -0.436 & -0.191 & 0.74 \\
\hline Continuance commitment & 6.00 & 29.00 & 19.80 & 4.62 & -0.471 & 0.732 & 0.65 \\
\hline Normative commitment & 6.00 & 30.00 & 18.34 & 5.33 & -0.128 & -0.186 & 0.74 \\
\hline
\end{tabular}

M, mean; SD, standard deviation; $\alpha$, Cronbach's alpha coefficient; PsyCap, psychological capital; UWES, Utrecht Work Engagement Scale.

TABLE 3: Pearson product-moment correlation coefficients.

\begin{tabular}{|c|c|c|c|c|c|c|c|c|c|c|c|c|}
\hline Variable & 1 & 2 & 3 & 4 & 5 & 6 & 7 & 8 & 9 & 10 & 11 & 12 \\
\hline 1. PsyCap total & - & - & - & - & - & - & - & - & - & - & - & - \\
\hline 2. Self-efficacy & $0.80 * * b$ & - & - & - & - & - & - & - & - & - & - & - \\
\hline 3. Resilience & $0.86 * * b$ & $0.63 * * b$ & - & - & - & - & - & - & - & - & - & - \\
\hline 4. Hope & $0.82 * * b$ & $0.68^{* * b}$ & $0.66^{* * b}$ & - & - & - & - & - & - & - & - & - \\
\hline 5. Optimism & $0.69 * * b$ & $0.55^{* * b}$ & $0.63^{* b}$ & $0.62^{* * \mathrm{~b}}$ & - & - & - & - & - & - & - & - \\
\hline 6. UWES total & $0.73 * * b$ & $0.42^{* * a}$ & $0.82^{* * \mathrm{~b}}$ & $0.44^{* * a}$ & $0.68^{* * b}$ & - & - & - & - & - & - & - \\
\hline 8. Dedication & $0.65^{* * b}$ & $0.35^{* * b}$ & $0.33 * * a$ & $0.32 * * a$ & $0.61 * * \mathrm{~b}$ & $0.95 * * \mathrm{~b}$ & $0.88^{* * b}$ & - & - & - & - & - \\
\hline 9. Absorption & $0.65^{* * b}$ & $0.39 * * \mathrm{~b}$ & $0.34^{* * a}$ & $0.42^{* * a}$ & $0.64^{* * b}$ & $0.76^{* * b}$ & $0.93^{* * b}$ & $0.84 * * \mathrm{~b}$ & - & - & - & - \\
\hline 10. Organisational commitment total & $0.35^{* * a}$ & $0.20 *$ & $0.33^{* * a}$ & $0.26 *$ & $0.34 * * a$ & $0.63 * * b$ & $0.61 * * b$ & $0.64 * * b$ & $0.52 * * b$ & - & - & - \\
\hline 11. Affective commitment & $0.51 * * \mathrm{~b}$ & $0.31^{* * a}$ & $0.44^{* * a}$ & $0.37^{* * a}$ & $0.56^{* * b}$ & $0.62 *$ *b & $0.64^{* * \mathrm{~b}}$ & $0.65^{* * \mathrm{~b}}$ & $0.54^{* * \mathrm{~b}}$ & $0.77^{* * \mathrm{~b}}$ & - & - \\
\hline 12. Continuance commitment & -0.28 & -0.87 & -0.03 & 0.03 & -0.03 & 0.13 & $0.27^{*}$ & $0.69 * * b$ & $0.41 * * a$ & $0.50^{* * \mathrm{~b}}$ & -0.01 & - \\
\hline 13. Normative commitment & $0.30 * * a$ & 0.15 & $0.27 *$ & 0.17 & $0.34 * * a$ & $0.34 * * a$ & $0.62^{* * b}$ & $0.57 * * \mathrm{~b}$ & $0.52 * * b$ & $0.88^{* * \mathrm{~b}}$ & $0.54^{* * \mathrm{~b}}$ & \\
\hline
\end{tabular}

PsyCap, psychological capital; UWES, Utrecht Work Engagement Scale.

a, $r>0.30$ Practically significant (medium effect)

,$r>0.50$ Practically significant (large effect)

$*^{*}, p<0.05$ Statistically significant; ${ }^{* *}, p<0.01$ Statistically significant 
between organisational commitment and resilience and optimism ( $p \leq 0.01 ; r=0.33$ and 0.34 , respectively). In addition, table 3 indicates that positive statistically- and practically-significant relationships were found between affective commitment and self-efficacy, resilience and hope ( $p \leq 0.01 ; r=0.31,0.44$ and 0.37 , respectively); as well as between affective commitment and optimism ( $p \leq 0.01$; $r=0.56$ ). A positive statistically-significant relationship was found between normative commitment and resilience ( $p \leq$ $0.05 ; r=0.27)$ and a positive statistically- and practicallysignificant relationship was found between normative commitment and optimism ( $p \leq 0.01 ; r=0.34)$.

\section{The relationship between the Utrecht Work Engagement Scale and Organisational Commitment Questionnaire}

Table 3 shows positive statistically- and practically-significant relationships between work engagement (total) and affective commitment $(p \leq 0.01 ; r=0.62)$ and between work engagement and normative commitment ( $p \leq 0.01 ; r=0.34$ ).

A further inspection of Table 3 shows that positive statisticallyand practically-significant relationships were found between organisational commitment (total score) and vigour, dedication and absorption $(p \leq 0.01 ; r=0.61,0.64$ and 0.52 , respectively). Statistically-positive and practically-significant relationships were found between affective commitment and vigour, dedication and absorption ( $p \leq 0.01 ; r=0.64$, 0.65 and 0.54 , respectively), as well as between continuance commitment and dedication and absorption ( $p \leq 0.01 ; r=0.69$ and 0.41 , respectively). There was also a statistically-significant relationship between continuance commitment and vigour ( $p \leq 0.05, r=0.27$ ). Positive statistically- and practicallysignificant relationships were found between normative commitment and vigour, dedication and absorption $(p \leq 0.01$; $r=0.62,0.57$ and 0.52 , respectively).

The findings reported above support the hypotheses of the present study: firstly, that PsyCap is related positively to work engagement (vigour, dedication and absorption); secondly, that PsyCap is related positively to organisational commitment (affective and normative commitment); and thirdly, that work engagement is related positively to organisational commitment (affective and normative commitment).

\section{Regression analysis}

Table 4 summarises the regression analysis with psychological capital and work engagement (PsyCap and UWES measure) as predictors of organisational commitment. Entry of the demographic variables as the first step of the regression analysis produced a statistical model where $F=(1.344)=0.250$; $p \geq 0.797$ accounts for approximately $2 \%$ of the variance in perceived organisational commitment as is explained by demographic variables. Entry of PsyCap as the second step of the regression analysis produces a statistical model of $F=(17.333)=4.163 ; p \geq 0.000$ in perceived organisational commitment. Entry of work engagement (UWES) together

TABLE 4: Hierarchical regression to determine the predictive value of the independent variables (PsyCap and UWES) on the dependent variable (Organisational commitment).

\begin{tabular}{|c|c|c|c|c|c|c|c|c|}
\hline Variable & $F$ & $\beta$ & SE & $R$ & $R^{2}$ & $\Delta R^{2}$ & $\bar{t}$ & $p$ \\
\hline \multicolumn{9}{|l|}{ Step 1} \\
\hline (Constant) & - & - & - & - & - & - & 9.969 & 0.000 \\
\hline Gender & - & -0.15 & 2.843 & - & - & - & -1.205 & 0.233 \\
\hline Age & - & 0.211 & 2.231 & - & - & - & 1.325 & 0.190 \\
\hline Marital status & - & -0.12 & 0.738 & - & - & - & -0.857 & 0.395 \\
\hline Tenure & - & 0.122 & 2.059 & - & - & - & 0.824 & 0.413 \\
\hline Qualification & - & -0.17 & 1.749 & - & - & - & -1.381 & 0.172 \\
\hline Experience & 1.344 & 0.032 & 0.733 & $0.337^{a}$ & 0.113 & 0.029 & 0.258 & 0.797 \\
\hline \multicolumn{9}{|l|}{ Step 2} \\
\hline (Constant) & - & - & - & - & - & - & 3.113 & 0.003 \\
\hline Gender & - & -0.18 & 2.540 & - & - & - & -1.647 & 0.105 \\
\hline Age & - & 0.143 & 2.001 & - & - & - & 0.996 & 0.323 \\
\hline Marital status & - & -0.12 & 0.658 & - & - & - & -0.967 & 0.338 \\
\hline Tenure & - & 0.243 & 1.879 & - & - & - & 1.799 & 0.077 \\
\hline Experience & - & 0.007 & 0.654 & - & - & - & 0.062 & 0.951 \\
\hline PsyCap & 17.333 & 0.453 & 0.070 & $0.554^{\mathrm{a}}$ & $0.307^{a}$ & 0.229 & 4.163 & $0.000^{*}$ \\
\hline \multicolumn{9}{|l|}{ Step 3} \\
\hline (Constant) & - & - & - & - & - & - & 3.770 & 0.000 \\
\hline Gender & - & -0.11 & 2.234 & - & - & - & -1.212 & 0.230 \\
\hline Age & - & 0.040 & 1.769 & - & - & - & 0.318 & 0.752 \\
\hline Marital status & - & -0.12 & 0.572 & - & - & - & -1.170 & 0.247 \\
\hline Tenure & - & $0.305^{*}$ & 1.646 & - & - & - & 2.578 & 0.012 \\
\hline Qualification & - & -0.10 & 1.384 & - & - & - & -1.081 & 0.284 \\
\hline Experience & - & 0.049 & 0.513 & - & - & - & 0.513 & 0.610 \\
\hline PsyCap & - & 0.067 & 0.081 & - & - & - & 0.531 & 0.597 \\
\hline UWES & 20.871 & $0.590 *$ & 0.062 & $0.696^{b}$ & $0.484^{*}$ & 0.416 & 4.568 & $0.000^{*}$ \\
\hline
\end{tabular}

PsyCap, psychological capital; UWES, Utrecht Work Engagement Scale; F, probability distribution (F-Ratio); $\beta$, standard regression coefficient; SE, standard error; $R$, multiple regression coefficient; $R^{2}$, proportion of variance accounted for; $\Delta R^{2}$, adjusted $\mathrm{R}$ square; $t$, test for independent mean; $p$, probability.

$R^{2}, r>0.30$ Practically significant (medium effect)
, proporion

,$r>0.30$ Practically significant (medium effect)
$b>0.50$ Practically significant (large effect)

,$r>0.50$ Practically significant (large
$*, p<0.000$ (Statistical significance) 
with PsyCap as the third step of the regression analysis produced a statistical model $F=(20.871)=4.568 ; p \geq 0.000)$, accounting for approximately $41 \%$ of the variance. In the final model, work engagement $(\beta=0.590 ; p \geq 0.000)$ statistically predicted organisational commitment and PsyCap $(\beta=0.067)$ did not.

\section{Discussion}

The purpose of the research was to determine the relationship between PsyCap, work engagement and organisational commitment amongst call centre employees; and also to determine whether PsyCap and work engagement hold predictive value for the organisational commitment of call centre employees.

The majority of participants in this research were women - a relatively young group with the majority younger than 35 years of age with less than 5 years' experience in the call centre. It is interesting to mention that $19.8 \%$ of the respondents had worked previously in a call centre, possibly suggesting that employees tend to stay in call centre work. Any conclusions fall beyond the scope of this research and further research in this regard is necessary.

\section{Reliability and validity of instruments}

The study found high levels of internal consistency reliabilities for the measuring instruments (and their subscales) used in this study. Cronbach alpha coefficients $(\alpha)$ were used as a reliability estimate and all, except continuous organisational commitment, were found to be acceptable according to the guideline of $\alpha \geq 0.70$ (Nunnally \& Bernstein, 1994). Based on research (Heymans, 2002), it was decided to include continuance commitment, although the Cronbach alpha was below that of 0.70 .

\section{Confirmatory factor analysis}

Confirmatory factor analysis of the PCQ found that a fourfactor model best fit the data. Conceptual and empirical analysis supports the four constructs of PsyCap as a core construct that is made up of four identified positive resources (hope, optimism, resilience and self-efficacy). These four constructs have thus been found to meet the operational definition and inclusion criteria of psychological capital (Avey et al., 2010a; Luthans, Avey \& Petera (2008); Luthans et al., 2008). A recent South African study confirmed a four-factor model of PCQ (Herbert, 2011). Analysis of the UWES found a three-factor model best suited the data. Most international studies have confirmed a three-factor model comprising vigour, dedication and absorption (Schaufeli et al., 2002). Studies from South Africa have also confirmed a threefactor model of the UWES (Barkhuizen \& Rothmann, 2006; Rothmann \& Jordaan, 2006). Confirmatory factor analysis conducted on the OCQ found that a three-factor model best fit the data. The findings confirm the three-factor model as proposed by Allen and Meyer (1990). International studies have confirmed a three-factor model consisting of affective, normative and continuance commitment (Shahnawaz \&
Jafri, 2009). South African studies have also confirmed a three-factor model of organisational commitment (Ferreira, Basson \& Coetzee, 2010; Lumley, 2010).

\section{Inferential statistics}

Pearson correlation coefficients were done and the results suggested that higher levels of PsyCap are associated with higher levels of work engagement and organisational commitment. Psychological capital as a personal resource can be implemented to enhance attitudinal outcomes such as work engagement and organisational commitment. This is supported by Halbesleben (2010) who found in a meta-analysis that personal resources (e.g. optimism and self-efficacy) are related strongly to work engagement. Furthermore, higher levels of work engagement are associated with higher levels of organisational commitment. Research studies conducted internationally have found that PsyCap is related positively to organisational commitment (Larson \& Luthans, 2006; Luthans et al. 2008). However, a stronger relationship was found between PsyCap and work engagement than between PsyCap and organisational commitment. The current findings support those of Shahnawaz and Jafri (2009) who found that PsyCap and organisational commitment were not related very strongly.

A study by Avey et al. (2008), with employees from a broad cross-section of organisations and jobs, found that PsyCap was related positively to their positive emotions which were, in turn, related to their attitudes of engagement. These findings can be interpreted within Fredrickson's (2003) broadenand-build framework, where the experience of positive emotions can propel people toward optimal individual and organisational functioning. Furthermore, the present findings indicated that work engagement and organisational commitment were related positively to each other. Schaufeli and Bakker (2004) showed that the experience of engagement is described as being a positive work-related experience and state of mind. Positive experiences and emotions are likely to result in positive work outcomes. The authors further note that engaged employees are likely to have a greater attachment to their organisation and a lower tendency to leave their organisation. The present study findings have been supported by international research studies that found a positive relationship between work engagement and organisational commitment (Saks, 2006; Sonnentag, 2003).

Psychological capital as a core construct has been found to be related to several workplace outcomes (Avey et al., 2008). The present study's findings support research that has shown that the overall core construct of PsyCap relates better to the outcomes of work engagement and organisational commitment than to the individual constructs (hope, optimism, resilience and self-efficacy) that make it up (Luthans et al., 2005). Psychological strengths can create tendencies that are favourable to work engagement (Strümpfer, 1990). Work engagement as a 'positive, fulfilling, work-related state of mind that is characterised by vigour, dedication and absorption' has a positive relationship with individual 
attitudes and behaviour (Harter, Schmidt \& Hayes, 2002; Schaufeli et al., 2002, p. 74). The present study's findings support the theoretical and empirical findings that PsyCap and desirable workplace attitudes and behaviours have a positive relationship (Avey et al., 2010a).

The findings of this study further indicated that the PsyCap subdimensions and work engagement subdimensions had a positive relationship. This is supported by studies that have established that personal resources such as self-efficacy and optimism predicted work engagement (Xanthopoulou, Bakker, Heuven, Demerouti \& Schaufeli, 2008). Roux (2010) found self-efficacy to be related positively to work engagement of employees in a South African organisation.

In addition, a positive relationship between PsyCap and organisational commitment subdimensions was found. There have been a number of studies that have tested the relationship between PsyCap and various employee attitudes (Avey, Reichard, Luthans \& Mhatre, 2011). In a study by McColl-Kennedy and Anderson (2005), there was evidence of a dependency link between optimism and commitment. Saks (2006) found that post-training self-efficacy mediated the relationship between training and job satisfaction, turnover intentions and organisational commitment.

The current findings showed a significant relationship between work engagement and organisational commitment. Employees with high organisational commitment are more likely to be enthusiastic about their work (engagement). Organisational commitment is an employee's identification with the organisation's goals and values and being attached affectively to the organisation (Mowday, Steers \& Porter, 1979). Work engagement is described by Macey and Schneider (2008, p. 12) as: 'positive affect associated with the job and the work setting, connoting or explicitly indicating feelings of persistence, vigour, energy, dedication, absorption, enthusiasm, alertness and pride'. Research has also shown that work engagement is an antecedent of organisational commitment. People who are deeply engaged in their work tend to be more committed to their organisations (Jackson et al., 2006; Saks, 2006). The findings in this study are supported by various research studies. Researchers, both internationally and nationally, have found a positive relationship between work engagement and organisational commitment (Field \& Buitendach, 2011; Rothmann \& Jordaan, 2006).

An interesting finding in this study was that the PsyCap construct of optimism displays a significant positive relationship with work engagement, as well as with the subdimensions of vigour, dedication and absorption. Furthermore, the findings of the current study have shown a statistically-significant as well as a practically-significant positive relationship between the PsyCap construct of optimism and organisational commitment and the subdimensions of normative commitment and affective commitment. Research studies have shown that optimism is related positively to employee engagement and employee performance (Medlin \& Faulk, 2011; Tombaugh, 2005). In addition, Bressler (2010) found that optimism had a positive relationship with affective commitment. A review of the literature supports the present study finding that optimism is overall more closely associated with positive psychology than the other constructs (Luthans et al., 2004).

A review of the literature suggests that optimism has a positive relationship with a positive, fulfilling work-related state of mind (work engagement) (Bakker et al., 2003). Furthermore, optimism has a positive relationship with an employee's belief and acceptance of the organisation's goals and values. This indicates a willingness by an employee to focus on helping the organisation achieve its goals and a desire to maintain organisational membership (affective commitment). Optimism has also been found to have a positive relationship with the moral belief or obligation that it is the right thing to remain with the organisation (normative commitment) (Shahnawaz \& Jafri, 2009).

Given its value in employee well-being, optimism must be encouraged and developed in intervention programmes within organisations (Peterson et al., 2009). In call centres, such interventions can enhance the resource capacities of employees. Having an optimistic outlook for call centre employees is critical with regard to the quality of their interaction with customers (Deery \& Kinnie, 2002). Ashkanasy and Daus (2002) have shown that individuals 'catch' on to the feelings of others and that positive expressions of emotion by call centre employees can create a favourable impression in a customer's mind.

\section{Predictive value of psychological capital and work engagement}

The second objective of the present study was to determine whether PsyCap and work engagement were predictive of organisational commitment. Hierarchical regression analysis was conducted with organisational commitment as the dependent variable and PsyCap and work engagement as the independent variables. Work engagement was found to be the best predictor of organisational commitment. This finding is supported by previous studies that have found work engagement to be predictive of organisational commitment (Schaufeli \& Bakker, 2004; Sonnentag, 2003). Schaufeli and Bakker (2004) reported that engaged employees are likely to have a greater attachment to their organisation and a lower tendency to leave their organisation. The psychological resources that are generated by an employee's positive emotions have a relationship with, and contribute to, desired work-related outcomes (Youssef \& Luthans, 2007). The present study's finding that work engagement is the only statistically-significant predictor of organisational commitment needs to be explored in future research studies. The reason for PsyCap not being predictive of organisational commitment needs to be further investigated.

To summarise, this study builds more evidence supporting a cognitive mediation theory (Weiss \& Cropanzano, 1996) of employees' emotions in the workplace. It brings to the 
understanding that employees' psychological beliefs, expectancies and appraisals (i.e., hope, optimism, resilience and self-efficacy) may be seen as a potential source of positive emotions and subsequent employees' attitudes and behaviours such as work engagement and organisational commitment.

Previous research also indicated that PsyCap as a personal resource can be developed. Organisations, such as call centres, can introduce programmes to develop PsyCap in order to bring about more favourable attitude outcomes such as work engagement and organisational commitment.

\section{Limitations of the study}

The cross-sectional survey method cannot determine causality amongst variables. A further limitation of this study is the use of self-reported questionnaires. These are used frequently as a preferred method of data collection in the social sciences (Babbie \& Mouton, 2001). Self-report data can give rise to response biases which could affect the reliability and validity of the data. Social desirability is one of the response biases that influences the results of studies that use self-report questionnaires (Goodwin, 2004). A further limitation of the study could be attributed to the small sample size of 106 and the use of a nonprobability sampling method, more specifically a convenience sampling method. These limit the generalisation of the results to a larger population of call centre employees.

\section{Recommendations for the organisation}

The findings in this study indicated that positive relationships exist between PsyCap, work engagement and organisational commitment. To facilitate efficiency and positive well-being amongst employees, it is recommended that call centres invest in the development of PsyCap (Avey et al., 2010a). A study by Luthans et al. (2006) found that human resource interventions aimed at developing the state-like construct of PsyCap can be facilitated by means of training sessions. The development of organisational interventions may increase call centre employees' personal resources which will, in turn, increase their PsyCap levels and facilitate increased employee wellness, work engagement and organisational commitment (Luthans et al., 2006). The development of PsyCap and positive employee attitudes and behaviours are expected to contribute to positive work-related outcomes (Donaldson \& Ko, 2010). Furthermore, the complementary nature of work engagement and organisational commitment is conducive to long-term performance and sustainable humanbased organisational competitive advantage (Youssef \& Luthans, 2007).

More specifically, optimism was found to have the strongest relationship with work engagement and organisational commitment in this study. This finding is useful in informing an emphasis on optimism in training interventions. Optimism, as a personal resource, can be developed to have favourable attitudinal outcomes such as work engagement and organisational commitment.
Avey, Nimnicht and Pigeon (2010b) maintain that measurement of PsyCap may inform an organisation of the vitality, psychological health and anticipated future performance of the organisation. Also, the use of a PsyCap measure may be of benefit in selection batteries for organisations. The selection and retention of employees who have a propensity to be higher in psychological capital may have a positive impact on work-related outcomes (Avey et al., 2010b). It is suggested that the use of a PsyCap measure could be useful in establishing call centre employee levels of PsyCap. This would be valuable in informing selection and retention strategies in the call centre industry.

\section{Recommendations for future research}

It is recommended that future studies make use of a longitudinal design to determine the causal relationships between the variables of the study. Future studies can overcome the limitations of the generalisation of the findings by using a larger sample size across different contexts. The study's finding on the predictive relationship between PsyCap and organisational commitment is a starting point for future research. Also, the psychometric properties of the PCQ need to be explored further in the South African context.

\section{Contribution}

The research contributes to the study of positive psychology in the workplace. More specifically, it is a contribution to the positive resource capacities of call centre employees within the South African context. The study adds to the existing literature on PsyCap and its relationships with the organisational outcomes of work engagement and organisational commitment. More specifically, the study highlights the importance of the role of optimism as a PsyCap subdimension with regard to its impact on work engagement and organisational commitment amongst call centre employees.

\section{Conclusion}

People spend most of their lives in their working environments. It is becoming of such importance that managers in organisations cannot ignore the human factor in general (and PsyCap in particular) in their quest for longterm survival and excellence.

These research findings will benefit all parties in the workplace and pave the way for the development of intervention programmes to develop the PsyCap of employees in organisations, which will then lead to them being more productive workers.

\section{Acknowledgements Competing interests}

The authors declare that they have no financial or personal relationship(s) which may have inappropriately influenced them in writing this article. 


\section{Authors' contributions}

J.C.S. (University of KwaZulu Natal) was the main researcher and J.H.B. (University of KwaZulu Natal) was the supervisor.

\section{References}

Allen, N.J., \& Meyer, J.P (1990). The measurement and antecedents of affective, continuance and normative commitment to the organization. Journal of Occupational and Organizational Psychology, 63(1), 1-18. http://dx.doi.org/10.1111/j.2044-8325.1990. tb00506.x

Arakawa, D., \& Greenberg, M. (2007). Optimistic managers and their influence on productivity and employee engagement in a technology organisation: implication for coaching psychologists. International Coaching Psychology Review, 2(1), 78-89.

Arzu Wasti, S. (2003). Organizational commitment, turnover intentions and the influence of cultural values. Journal of Occupational and Organizational Psychology, 76(3), 303-321. http://dx.doi.org/10.1348/096317903769647193

Ashkanasy, N.M., \& Daus, C.S. (2002). Emotion in the workplace: the new challenge for managers. Academy of Management Executive, 16(1), 76-86. http://dx.doi. org/10.5465/AME.2002.6640191

Avey, J.B., Luthans, F., \& Jensen, S.M. (2009). Psychological capital: a positive resource for combating employee stress and turnover. Human Resource Management, 48(5), 677-693. http://dx.doi.org/10.1002/hrm.20294

Avey, J.B., Luthans, F., \& Youssef, C.M. (2010a). The additive value of positive psychological capital in predicting work attitudes and behaviors. Journal of Management, 36(2), 430-452. http://dx.doi.org/10.1177/0149206308329961

Avey, J.B., Nimnicht, J.L. \& Pigeon, N.G. (2010b). Two field studies examining the association between positive psychological capital and employee performance. Leadership \& Organizational Development Journal, 31(5), 384-401. http://dx.dol. org/10.1108/01437731011056425

Avey, J.B., Reichard, R.J., \& Luthans, F., \& Mhatre, K.H. (2011). Meta-analysis of the impact of positive psychological capital on employee attitudes, behaviours and performance. Human Resource Development Quarterly, 22(2), 127-152. http:// dx.doi.org/10.1002/hrdq.20070

Avey, J.B., Wernsing, T.S., \& Luthans, F. (2008). Can positive employees help positive organizational change? Impact of psychological capital and emotions on relevant attitudes and behaviors. The Journal of Applied Behavioral Science, 44(1), 48-70. http://dx.doi.org/10.1177/0021886307311470

Babbie, E.R., \& Mouton, J. (2001). The practice of social research. Cape Town: Oxford.

Bakker, A., Demerouti, E., \& Schaufeli, W. (2003). Dual processes at work in a call centre: an application of the job demands-resources model. European Journal of Work and Organizational Psychology, 12(4), 393-417. http://dx.doi.org/10.1080/ 13594320344000165

Bandura, A. (2000). Exercise of human agency through collective efficacy. Current Directions in Psychological Science, 9(3), 75-78. http:// dx.doi.org/10.1111/1467 8721.00064

Barkhuizen, N., \& Rothmann, S. (2006). Work engagement of academic staff in South African higher education institutions. Management Dynamics, 15(1), 38-46.

Bauer, T.N., Bodner, T., Erdogan, B., Truxillo, D.M., \& Tucker, J.S. (2007). Newcomer adjustment during organizational socialization: A meta-analytic review of antecedents,
outcomes, and methods. Journal of Applied Psychology, 92(3), 707-721. http:// outcomes, and methods. Journal of Applied Psychology,
dx.doi.org/10.1037/0021-9010.92.3.707, PMid:17484552

Baumgardner, S.R., \& Crothers, M.K. (2010). Positive Psychology. New Jersey: Pearson Education.

Bressler, M. (2010). Planning and projecting critical human resource needs: the relationship between hope, optimism, organizational commitment, and turnover intention among U.S. Army reserve soldiers. Journal of Behavioral Studies in Business, 3(1), 12 pages.

Buys, C., \& Rothmann, S. (2010). Burnout and engagement of reformed church ministers. SA Journal of Industrial Psychology/SA Tydskrif vir Bedryfsielkunde, 36(1), Art. \#825, 11 pages. http://dx.doi.org/10.4102/sajip.v36i1.82

Carver, C., \& Scheier, M. (2002). Optimism. In C.R. Snyder \& S. Lopez (Eds.), Handbook of positive psychology (pp. 231-243). New York: Oxford University Press.

Cohen, J. (1988). Statistical power analysis for behavioural sciences (2nd edn.). Hillsdale, NJ: Lawrence Erlbaum \& Associates.

Deery, S., \& Kinnie, N. (2002). Call centres and beyond: a thematic evaluation. Human Resource Management Journal, 12(4), 3-13. http://dx.doi.org/10.1111/ j.17488583.2002.tb00074.x

Demerouti, E., Bakker, A.B., de Jonge, J., Janssen, P., \& Schaufeli, W.B. (2001). Burnout and engagement at work as a function of demands and control. Scandinavian
Journal of Work, Environment \& Health, 27(4), 279-286. http://dx.doi.org/ Journal of Work, Envi
$10.5271 /$ sjweh.615

Donaldson, S.I., \& Ko, I. (2010). Positive organizational psychology, behavior, and scholarship: A review of the emerging literature and evidence base. The Journal of scholarship: A review of the emerging literature and evidence base. The Journal of
Positive Psychology, 5(3),177-191. http://dx.doi.org/10.1080/17439761003790930

Duggleby, W., Cooper, D., \& Penz, K. (2009). Hope, self-efficacy, spiritual well-being and job satisfaction. Journal of Advanced Nursing, 65(11), 2376-2385. http:// dx.doi.org/10.1111/j.1365-2648.2009.05094.x, PMid:19737323

Ferreira, N., Basson, J., \& Coetzee, M. (2010). Psychological career resources in relation to organisational commitment: An exploratory study. SA Journal of Human Resource Management/SA Tydskrif vir Menslikehulpbronbestuur, 8(1), Art. \#284, 10 pages. http://dx.doi.org/10.4102/sajhrm.v8i1.284

Field, A. (2005). Discovering statistics using SPSS. (2nd edn.). London: Sage Publications.
Field, L.K., \& Buitendach, J.H. (2011). Happiness, work engagement and organisational commitment of support staff at a tertiary education institution in South Africa. $S A$ Journal of Industrial Psychology/SA Tydskrif vir Bedryfsielkunde, 37(1), Art. \#946, Journal of Industrial Psychology/SA Tydskrif vir Bedryfsic
10 pages. http://dx.doi.org/10.4102/sajip.v37i1.946

Fredrickson, B.L. (2003). Positive emotions and upward spirals in organizational settings. In K. Cameron, J. Dutton \& R. Quinn (Eds.), Positive organizational scholarship (pp. 163-175). San Francisco: Berrett Koehler.

Fredrickson, B.L. (2004). The broaden-and-build theory of positive emotions. The Roya Society, Published online 17 August 2004. Retrieved on January 10, 2011 from $\mathrm{http}: / /$ rstb.royalsocietypublishing.org/content/359/1449/1367.full.pdf

Goodwin, C.J. (2004). Research in psychology: methods and design. (4thedn.). Hoboken, N.J.: John Wiley \& Sons, Inc.

Halbesleben, J.R.B. (2010). A meta-analysis of work engagement: relationships with burnout, demands, resources, and consequences. In A.B. Bakker, \& M.P. Leiter (Eds.), Work engagement: a handbook of essential theory and research (pp. 102(Eds.), Work engagement: a handbook
117). New: Psychology Press.

Halbesleben, J.R.B., \& Wheeler, A.R. (2008). The relative roles of engagement and embeddedness in predicting job performance and intention to leave. Work \& Stress, 22(3), 242-256. http://dx.doi.org/10.1080/02678370802383962

Harris, G.E., \& Cameron, J.E. (2005). Multiple dimensions of organizational identification and commitment as predictors of turnover intentions and psychological wellbeing. Canadian Journal of Behavioural Science, 37(3), 159-169. http://dx.doi. org/10.1037/h0087253

Harter, J.K., Schmidt, F.L., \& Hayes, T.L. (2002). Business-unit-level relationship between employee satisfaction, employee engagement, and business outcomes: a metaanalysis. Journal of Applied Psychology, 87(2), 268-279. http://dx.doi.org/10.1037/ 0021-9010.87.2.268, PMid:12002955

Herbert, M. (2011). An exploration of the relationships between psychological capital (hope, optimism, self efficacy, resilience) occupational stress, burnout and employee
engagement. Unpublished Master's thesis, University of Stellenbosch, South Africa.

Heymans, D.R. (2002). The relationship between job insecurity, job satisfaction and organizational commitment of maintenance workers in a parastatal. Unpublished Master's dissertation, Vaal Triangle Campus of the Potchefstroom University, Vanderbijlpark.

Holman, D. (2003) Phoning in sick? An overview of employee stress in call centres. Leadership \& Organization Development Journal, 24(3), 123-130. http://dx.doi. org/10.1108/01437730310469543

Huysamen, G.K. (1994). Methodology for the social and behavioural sciences. Pretoria: Southern Book.

IBM SPSS Inc. (2012). IBM SPSS 21.0 for Windows. Chicago, IL: SPSS Incorporated.

Jackson, L.T.B., Rothmann, S., \& van de Vijver, F.J.R. (2006). A model of work-related well-being for educators in South Africa. Stress \& Health, 22(4), 263-274. http:// dx.doi.org/10.1002/smi.1098

Janse van Rensburg, Y. (2010). Engagement in call centres: exploring eliciting factors. Unpublished Master's thesis, University of Stellenbosch, South Africa.

Kahn, W.A. (1990). Psychological conditions of personal engagement and disengagement at work. Academy of Management Journal, 33(4), 692-724. http://dx.doi.org/ $10.2307 / 256287$

Larson, M., \& Luthans, F. (2006). Potential added value of psychological capital in predicting work attitudes. Journal of Leadership \& Organizational Studies, 13(2) 75-92. http://dx.doi.org/10.1177/10717919070130020601

Lombard, A. (2009). Call centres. A scary workplace? Retrieved January 10, 2011 from http://www.skillsportal.co.za/page/training/training companies/call centre/201893-Call-centres-a-scary-work-place

Lumley, E. (2010). The relationship between career anchors, job satisfaction and organisational commitment. Unpublished Master's thesis, University of South Africa, Pretoria, South Africa.

Luthans, F. (2002a). Positive organizational behaviour: developing and managing psychological strengths. Academy of Management Executive, 16(1), 57-72. http:// dx.doi.org/10.5465/AME.2002.6640181

Luthans, F. (2002b). The need for and meaning of positive organizational behaviour Journal of Organizational Behavior, 23, 695-706. http://dx.doi.org/10.1002/job.165

Luthans, F., Avey, J.B., Avolio, B.J., Norman, S.M., \& Combs, G.M. (2006). Psychological capital development: toward a micro-intervention. Journal of Organizational Behaviour, 27, 387-393. http://dx.doi.org/10.1002/job.373

Luthans, F., Avey, J.B., \& Petera, J.L. (2008). Experimental analysis of a web-based training intervention to develop positive psychological capital. Academy of Managerial Learning \& Education, 7(2), 209-221. http://dx.doi.org/10.5465/ AMLE.2008.32712618

Luthans, F., Avolio, B.J., Avey, J.B., \& Norman, S.M. (2007a). Positive psychological capital: measurement and relationship with performance and Satist Psychology, 60(3), 541-572. http://dx.doi.org/10.1111/j.1744-6570.2007.00083.x

Luthans, F., Avolio, B., Walumbwa, F., \& Li, W. (2005). The psychological capital of Chinese workers: exploring the relationship with performance. Management and Organization Review, 1(2), 247-269. http://dx.doi.org/10.1111/j.1740-8784.2005. O0011.x

Luthans, F., \& Jensen, S.M. (2002). Hope: a new positive strength for human resource development. Human Resource Development Review, 1(3), 304-322. http://dx.doi. org $/ 10.1177 / 1534484302013003$

Luthans, F., Luthans, K.W., \& Luthans, B.C. (2004). Positive Psychological Capital: Beyond human and social capital. Business Horizons, 47(1), 45-50. http://dx.doi.org/10.1016/ j.bushor.2003.11.007

Luthans, F., Norman, S.M., Avolio, B.J., \& Avey, J.B. (2008). The mediating role of psychological capital in the supportive organizational climate-employee performance relationship. Journal of Organizational Behavior, 29(2), 219-238. http://dx.doi.org/ 10.1002/job.507 
Luthans, F., \& Youssef, C.M. (2004). Human, social, and now positive psychological capital management: investing in people for competitive advantage. Organizational Dynamics, 33, 143-160. http://dx.doi.org/10.1016/j.orgdyn.2004.01.003

Luthans, F. Youssef, C.M. \& Avolio, B.J. (2007b). Psychological capital: developing the human competitive edge. New York: Oxford University Press.

Macey, W.H., \& Schneider, B. (2008). The meaning of work engagement. Industria and Organizational Psychology, 1, 3-30. http://dx.doi.org/10.1111/j.1754-9434. 2007.0002.x

Maslach, C., \& Leiter, M.P. (1997). The truth about burnout: how organizations cause personal stress and what to do about it. San Francisco: Jossey-Bass. PMid:9332965

May, D.R., Gilson, R.L., \& Harter, L.M. (2004). The psychological conditions of meaningfulness, safety and availability and the engagement of the human spirit at work. Journal of Occupational and Organizational Psychology, 77(1), 11-37. http://dx.doi.org/10.1348/096317904322915892

McColl-Kennedy, J.R. \& Anderson, R.D. (2005). Subordinate-manager gender combination and perceived leadership style influence on emotions, self-esteem and organizational commitment. Journal of Business Research, 58(2), 115-125. http://dx.doi.org/10.1016/S0148-2963(03)00112-7

Medlin, B., \& Faulk, L. (2011). The relationship between optimism and engagement: the impact on student performance. Research in Higher Education Journal, 13, 9 pages.

Mowday, R.T., Porter, L.W., \& Steers, R.M. (1982). Employee-organisation linkages: the psychology of commitment, absenteeism, and turnover. New York: Academic Press.

Mowday, R.T., Steers, R.M., \& Porter, L.W. (1979). The measurement of organizational commitment. Journal of Vocational Behaviour, 14(2), 224-247. http://dx.doi. org/10.1016/0001-8791(79)90072-1

Nunnally, J.C., \& Bernstein, I.H. (1994). Psychometric theory (3rd edn.). New York: McGraw-Hill.

Peterson, C. (2000). The future of optimism. American Psychologist, 55(1), 44-55. http://dx.doi.org/10.1037/0003-066X.55.1.44, PMid:11392864

Peterson, S.J. Walumbwa, F.O, Byron, K. \& Myrowitz, J. (2009). CEO positive psychological traits, transformational leadership, and firm performance in hightechnology start-up and established firms. Journal of Management, 35(2), 348-368. http://dx.doi.org/10.1177/0149206307312512

Philippe, F.L., Lecours, S., \& Beaulieu-Pelletier, G. (2008). Resilience and positive emotions: Examining the role of emotional memories. Journal of Personality, 77(1), 139-175. http://dx.doi.org/10.1111/j.1467-6494.2008.00541.x, PMid:19077002

Rothbard, N.P (2001). Enriching or depleting? The dynamics of engagement in work and family roles. Administrative Science Quarterly, 46(4), 655-684. http://dx.doi. org/10.2307/3094827

Rothmann, S. (2003). Burnout and engagement: a South African perspective. SA Journal of Industrial Psychology/SA Tydskrif vir Bedryfsielkunde, 29(4), 16-25.

Rothmann, S., \& Essenko, N. (2007). Job characteristics, optimism, burnout, and ill health of support staff in a higher education institution in South Africa. South African Journal of Psychology, 37(1), 135-152. http://dx.doi.org/10.1177/008124630703700110

Rothmann, S., \& Jordaan, G.M.E. (2006). Job demands, job resources and work engagement of academic staff in South African higher education institutions. $S A$ Journal of Industrial Psychology/SA Tydskrif vir Bedryfsielkunde, 32(4), 87-96.

Roux, S. (2010). The relationship between authentic leadership, optimism, self-efficacy and work engagement: An exploratory study. Unpublished Master's thesis, Stellenbosch University, South Africa.

Rutter, M. (1987). Psychosocial resilience and protective mechanisms. American Journa of Orthopsychiatry, 57(3), 316-331. http://dx.doi.org/10.1111/j.1939-0025.1987. tb03541.x

Saks, A.M. (2006). Antecedents and consequences of employee engagement Journal of Managerial Psychology, 21(7), 600-619. http://dx.doi.org/10.1108/ 02683940610690169

Schaufeli, W.B., \& Bakker, A.B. (2004). Job demands, job resources, and their relationship with burnout and engagement: a multi-sample study. Journal of Organizational Behavior, 25(3), 293-315. http://dx.doi.org/10.1002/job.248
Schaufeli, W.B., Salanova, M., González-Romá, V., \& Bakker, A.B. (2002). The measurement of engagement and burnout: a two sample confirmatory factor analytic approach. Journal of Happiness Studies, 3, 71-92.

Shahnawaz, M.G., \& Jafri, H. (2009). Psychological capital as predictors of organizational commitment and organizational citizenship behaviour. Journal of the Indian Academy of Applied Psychology, 35, 78-84.

Shaughnessy, J.J., \& Zechmeister, J.S. (2000). Research Methods in Psychology (5th edn.) New York: McGraw-Hill. PMCid:PMC1987640

Sinha, S. P. Talwar, T., \& Rajpal, R. (2002). Correlational study of organizational commitment, self-efficacy and psychological barriers to technological change. Psychologia, 45(3), 176-183. http://dx.doi.org/10.2117/psysoc.2002.176

Snyder, C.R. (2002). Hope theory: rainbows in the mind. Psychological Inquiry, 13(4), 249-275. http://dx.doi.org/10.1207/S15327965PLI1304_01

Snyder, C.R., Irving, L., \& Anderson, J.R. (1991). Hope and health: measuring the will and the ways. In C.R. Snyder \& D.R. Forsyth (Eds.), Handbook of social and clinical psychology: the health perspective (pp. 285-307). Elmsford, NY: Pergamon Press

Sonnentag, S. (2003). Recovery, work engagement, and proactive behaviour: a new look at the interface between nonwork and work. Journal of Applied Psychology, 88(3), 518-528. http://dx.doi.org/10.1037/0021-9010.88.3.518, PMid:12814299

Stajkovic, A.D., \& Luthans, F. (1998). Social cognitive theory and self-efficacy: Going beyond traditional motivational and behavioural approaches. Organizational Dynamics, 26(4), 62-74. http://dx.doi.org/10.1016/S0090-2616(98)90006-7

Steyn, R. (2011). Optimism, self-efficacy and meaningfulness: towards a salutogenic model of occupational wellbeing. Unpublished Master's thesis, University of Stellenbosch, South Africa.

Storm, K., \& Rothmann, S. (2003). A psychometric analysis of the Utrecht Work Engagement Scale in the South African Police Service. SA Journal of Industrial Psychology/SA Tydskrif vir Bedryfsielkunde, 29(4), 62-70.

Strümpfer, D.J.W. (1990). Salutogenesis: A new paradigm. South African Journal of Psychology, 20(4), 265-276. http://dx.doi.org/10.1177/008124639002000406

Suliman, A.M., \& lles, P.A. (2000). Is continuance commitment beneficial to organizations? Commitment-performance relationship. a new look. Journal of Manageria Psychology, 15(5), 407-422. http://dx.doi.org/10.1108/02683940010337158

Swart, J. (2006). The relationship between job characteristics, work wellness and workrelated flow of call centre agents in an insurance company. Mini-dissertation. Industrial Psychology Honours. Potchefstroom Campus of the North-West University, Potchefstroom.

Thomas, S. (2010). SA gets the call. Financial Mail. Retrieved January 25, 2011, from http://www.callingthecape.org

Tombaugh, J.R. (2005). Positive leadership yields performance and profitability: effective organizations develop their strengths. Development and Learning in Organizations, 19(3), 15-17. http://dx.doi.org/10.1108/14777280510590031

Youssef, C.M., \& Luthans, F. (2007). Positive organizational behavior in the workplace: the impact of hope, optimism, and resilience. Journal of Management, 33(5) 774-800. http://dx.doi.org/10.1177/0149206307305562

Youssef, C.M., \& Luthans, F. (2008). Leveraging psychological capital in virtuous organizations: why and how. In C. Manz, K. Cameron, K. Manz, \& R. Marx (Eds.). The virtuous organization (pp. 131-162). Hackensack, NJ: World Scientific Publishers.

Weick, K.E., \& Quinn, R.E. (1999). Organizational change and development. Annua Review of Psychology, 50, 361-386. http://dx.doi.org/10.1146/annurev.psych.50. Review of Psychology,
1.361 , PMid:15012461

Weiss, H.M., \& Cropanzano, R. (1996). Affective events theory. In B.Shaw \& L.L. Cummings (Eds.), Research in organizational behaviour: An annual series of analytical essays and critical reviews (pp. 1-74). Greenwich, CT: JAI Press.

Xanthopoulou, D., Bakker, A.B., Heuven, E., Demerouti, E., \& Schaufeli, W.B. (2008). Working in the sky: a diary study on work engagement among flight attendants. Journal of Occupational Health Psychology, 13(4), 345-356. http://dx.doi.org/ 10.1037/1076-8998.13.4.345, PMid:18837629

Zapf, P.F., Isic, A., Bechtoldt, M., \& Blau, P. (2003). What is typical for call centre jobs? Job characteristics, and service interactions in different call centres. European Journal of Work and Organizational Psychology, 12(4), 311-340. http://dx.doi. org/10.1080/13594320344000183 